See discussions, stats, and author profiles for this publication at: https://www.researchgate.net/publication/265025292

\title{
Executive Branch Self-Policing in Times of Crisis: The Challenges for Conscientious Legal Analysis
}

Article

1

1 author:

Peter M. Shane

The Ohio State University

53 PUBLICATIONS 247 CITATIONS

SEE PROFILE 


\title{
Executive Branch Self-Policing in Times of Crisis: The Challenges for Conscientious Legal Analysis
}

\begin{abstract}
Peter M. Shane*
Presidential advisers, both Democratic and Republican, long ago discovered ways to magnify presidential power at the cost of legal principles and the system of checks and balances. This essay briefly considers the limits to executive branch capacity to provide reliable legal and constitutional analysis in times of emergency, including covert military operations. It highlights the special risks government faces when the circle of presidential advisers narrows because of highly classified operations and there is less opportunity for senior officials, including attorneys, to pass judgment on pending initiatives.
\end{abstract}

\section{THE HISTORICAL PATTERN}

Following the terrorist attacks of September 11, 2001, the Bush administration received legal advice from attorneys within the Justice Department and other agencies purporting to afford support for warrantless surveillance by the National Security Agency (NSA), the detention of enemy combatants, the creation of military tribunals, the use of coercive methods of interrogation, and the rendition of suspects to other countries for interrogation and torture. All of these initiatives relied on broad claims of unilateral presidential power. Legal memoranda - many of them secret were later subjected to severe criticism after they were made public. ${ }^{1}$

In many respects, the Bush administration's claims of power followed a pattern set by other administrations that decided to elevate presidential power over legal and democratic constraints: the Tonkin Gulf Resolution of August 1964 (based on a reported second attack that we now know did not occur $^{2}$ ); the Watergate break-in and subsequent cover-up; the abuses within

* Jacob E. Davis and Jacob E. Davis II Chair in Law, The Ohio State University Moritz School of Law. From 1978 to 1981, I served in the Office of Legal Counsel, U.S. Department of Justice. In preparing this essay, I have quoted liberally from my book, Peter M. Shane, Madison's Nightmare: How Executive Power Threatens American DEMOCRACY (2009). I am grateful to Louis Fisher for instigating this essay. Those who toil for any significant time in the separation of powers orchard will soon and repeatedly find themselves significantly indebted to Lou for his prolific, well-informed, and insightful scholarship.

1. Harold H. Bruff, Bad Advice: Bush's Lawyers in the War on Terror 209 (2009).

2. Id. at 52-60, 66-67, 101-105; Ryan M. Check \& Afsheen John Radsan, One 
the intelligence community exposed by the Church Committee investigations in the 1970s; assistance to the Contra rebels in Nicaragua in the 1980s, leading to the Iran-Contra Affair; and the unauthorized war against Serbia in 1999. The problem of illegal and unconstitutional activity within the executive branch has become chronic, raising questions whether remedies are available to minimize this chronic threat.

Our Constitution was founded on the hope that government can be structured to limit the ambitions of public officials who are tempted to abuse their power. What we find, instead, is a willingness to abandon the system of checks and balances to facilitate prompt action, often at the cost of individual liberties and constitutional violations. There are many ways to summarize this trend. I call it "presidentialism," the assertion that what we need in times of crisis (real or contrived) is a President free to act as necessary, even if in violation of statutes, treaties, and the Constitution. Dismissed from our political system is the understanding that at the heart of constitutionalism is a willingness and desire to form public policy through consensus and accommodation. I call institutional practices that support consensus and accommodation "pluralist." Part of the impetus toward concentrating power in the executive branch is the belief, which I consider false, that the President is better able and more likely to operate in the "national interest" under presidentialist, rather than pluralist arrangements.

The risks of moving in this direction are heightened with regard to foreign and military affairs. In this realm, policies within the executive branch are developed in a climate of isolation and ideological rigidity, predictably undermining the soundness of presidential decisions. Government attorneys are supposed to operate as a check on abuses of government power. Too often, in matters of national security, they are likely to be abettors. Problems in the past will continue into the future unless we rededicate ourselves to the pluralistic government of checks and balances that James Madison and his colleagues designed. Unfortunately, the campaign to "imperialize" the presidency reflects the determined work of many players, not just in the Oval Office or in Congress but also in courtrooms, lawyers' offices, and scholarly law reviews.

The choice between presidentialism and pluralism is crucial for constitutional government. Presidents who believe they are constitutionally entitled to preserve all decisionmaking power in their own hands are likely to attract a group of actors and advisers that will be too small and too

Lantern in the Darkest Night: The CIA's Inspector General, 4 J. NAT'L SECURITY L. \& POL'Y 247, 270-278 (2010). In 2005, NSA released an agency study that concluded that what had been reported as a second attack in the Gulf of Tonkin in August 1964 was actually late signals coming from the first. The agency report is available at http://www. nsa.gov/public_info/_files/gulf_of_tonkin/articles/rel1_skunks_bogies.pdf

3. Peter M. Shane, Madison's Nightmare: How Executive Power Threatens AMERICAN DEMOCRACY 82-83 (2009). 
homogeneous for best results. The dangers of presidentialism are evident in two costly wars: the Vietnam War in the 1960s-1970s and the Iraq war that began in March 2003. It is pluralism that is most likely to assure the advantages of open discussion, competing perspectives, and the conscientious weighing of diverse options, both within and beyond the bureaucracy.

The escalation of the war in Vietnam is surely one of the most tragic examples of presidentialism at work. Decisionmaking was shallow, ill informed, hostile to genuine debate, unwilling to confront uncertainties about basic issues, and driven more by wishful thinking and by perceived political momentum than by sound interpretations of fact. Our military policy was never seriously tested as to its underlying assumptions about the nature of the conflict and the soundness of alternative strategies. The governing political imperative was never to admit error. Presidential advisers fed the White House only the spin it wanted to hear. The ascendancy of Richard Nixon to the presidency exacerbated the penchant for tightly controlled executive branch decisionmaking and the affinity for secrecy and deception in prosecuting the war. ${ }^{4}$

The March 2003 U.S. invasion of Iraq - which both diverted American attention from Afghanistan and all but inevitably increased the regional power of our weightier adversary, Iran - was arguably even a worse disaster for American interests. In many respects, it appears to have replayed an earlier script. The Bush administration followed flawed intelligence and made policy by wishful thinking. Worst-case scenarios about Iraq's nuclear and unconventional weapons programs were offered to justify the invasion, while best-case scenarios predicted how American troops would be welcomed. Intelligence was overplayed or underplayed, depending on how it could support the invasion. Decisionmakers suppressed personal doubts in the face of what they believed to be conclusions already reached by higher authorities. False claims were made, or strongly implied, about a connection between Iraq and al Qaeda. The presentation by Secretary of State Colin Powell before the U.N. Security Council in February 2003, providing key support for the invasion, was deeply flawed by unreliable and false intelligence. ${ }^{5}$ Other deficiencies were evident, including invading the country with insufficient forces to make it secure and protect its infrastructure after toppling Saddam Hussein. According to Paul Pillar, the CIA's national intelligence officer for the Near East and South Asia in 2002, "For any analyst, favorable attention to policymakers is a benchmark of success. There was a natural bias in favor of intelligence production that supported, rather than undermined, policies already set." ${ }^{, 6}$ In short,

4. Id. at 65-68.

5. Id. at 71 .

6. Michael R. Gordon \& Bernard E. Trainor, Cobra II: The Inside Story of 
presidential unilateralism imposed a kind of ideological discipline that disabled sound analysis.

In making these military commitments, a recurrent problem is "agenda overload." An internal atmosphere of pressure and urgency will push groups and officials to premature conclusions. In order to obtain a President's or even a Secretary's attention, there will be a profoundly felt need to shrink the range of facts or issues under debate, to treat decisions already made as beyond rethinking, and to generally economize one's concentration on any particular item. As an operation drags out, important decisions will often be made on the basis of decisionmakers' shallow analyses. The problem of unreliable information is intensified if Congress is not part of the policy making process. During both the Vietnam and Iraq episodes, senior members of Congress with foreign policy experience would have felt freer than presidential subordinates to test key assumptions and challenge the quality of information.

\section{THE BREAKDOWN OF GOVERNMENT LAWYERING}

The military and foreign policy disasters generated by presidential unilateralism demonstrate the practical importance of maintaining a pluralist view of checks and balances. Political officials are not simply rational actors who respond with dispassionate calculation to evidence and circumstance. Facts and options are always filtered through ideological prisms. Presidentialism narrows the prism. Pluralism works to offset that filtering. Pluralism guards against too much distortion by seeking to maximize the number of meaningful institutional voices in the policy making process.

Equally troubling is the risk of presidentialism to the rule of law. Even in normal times, a heavy burden falls on government attorneys in virtually every agency. Government lawyering frequently represents the exclusive avenue through which the law is actually brought to bear on decisionmaking. This professional review within the executive branch is crucial. Most government decisions are simply too low in visibility, or too diffuse in impact, to elicit judicial review or congressional oversight as ways of monitoring legal compliance. Yet, the ideological prism of presidentialism can bend the light of the law so that nothing is seen other than the claimed prerogatives of the sitting chief executive. Champions of executive power - even skilled lawyers who should know better - wind up asserting that, to an extraordinary extent, the President as a matter of constitutional entitlement is simply not subject to legal regulation by either of the other two branches of government.

THE INVASION AND OCCUPATION OF IRAQ 154 (2006). 
Government attorneys must understand their unique roles as both advisers and advocates. In adversarial proceedings before courts of law, it may be fine for each of two contesting sides, including the government, to have a zealous, and not wholly impartial, presentation, with the judge acting as a neutral decisionmaker. But in their advisory function, government lawyers must play a more objective, even quasi-adjudicative, role. They must give the law their most conscientious interpretation. If they fail in that task, frequently there will be no one else effectively situated to do the job of assuring diligence in legal compliance. Government lawyers imbued with the ideology of presidentialism too easily abandon their professional obligations as advisers and too readily become ethically blinkered advocates for unchecked executive power.

Jack Goldsmith headed the Office of Legal Counsel (OLC) for a little less than ten months in 2003-2004. Of the work done by some government attorneys and top officials after 9/11, he said they dealt with FISA limitations on warrantless surveillance by the National Security Agency (NSA) "the way they dealt with other laws they didn't like: they blew through them in secret based on flimsy legal opinions that they guarded closely so no one could question the legal basis for the operations." " $\mathrm{He}$ describes a 2003 meeting with David Addington, who was Counsel and later Chief of Staff to Vice President Dick Cheney, in which Addington denied the NSA Inspector General's request to see a copy of OLC's legal analysis in support of the NSA surveillance program. Before Goldsmith arrived at OLC, "not even NSA lawyers were allowed to see the Justice Department's legal analysis of what NSA was doing.","

OLC's analysis of the legality of NSA surveillance, issued on January 19, 2006, justified the program on two grounds: the President's inherent war powers and the Authorization for Use of Military Force (AUMF). However, the AUMF did not say anything about electronic surveillance. In 1978, Congress expressly stated that no statute other than the Foreign Intelligence Surveillance Act (FISA) or Title III - the law that applies to ordinary federal criminal prosecution - provides authority for electronic surveillance by the federal government. The AUMF could supersede FISA by repealing it, but only by making the repeal explicit. An argument that the AUMF implicitly repealed FISA necessarily falls short. OLC also argued that the President had an inherent constitutional power to conduct the NSA program no matter what FISA said. According to OLC, if FISA of 1978 , as amended, were read to preclude the NSA program, the statute would be unconstitutional. ${ }^{9}$

7. Jack Goldsmith, The Terror Presidency: LAW AND Judgment Inside the BUSH ADMINISTRATION 181 (2007).

8. Id. at 182 .

9. U.S. Justice Department, Legal Authorities Supporting the Activities of 
What prompted the Justice Department to argue in this fashion? One answer might be that Justice Department lawyers are institutionally expected to advocate for the President's powers and simply adopt the most ambitious arguments consistent with appropriate standards of professional competence in legal research and analysis. However, it is not the responsibility of Justice Department lawyers to advocate for every contemplated assertion of presidential authority, no matter how far-fetched. Even in my brief period at Justice, I witnessed multiple and significant examples of Department lawyers refusing to provide analytic support for legally ill-conceived proposals for executive action. Moreover, it is difficult to make a case for the professional competence of the FISA memorandum. Although the Justice Department manages to elaborate its views in over forty pages of single-spaced and highly technical verbiage, its memorandum never confronts the enormity of the initiative it is endorsing or the power of alternative arguments. Instead, it proffers distinctions from contrary precedents that are often, in a word, silly. Even if the authors felt institutionally constrained to reach a particular bottom line, the failure to assert any principle limiting the claims being made and the too-frequent lack of rhetorical judgment in structuring their argument suggest something other than diligent lawyering was at play.

What accounted for the bad arguments was political and professional pressure. When I worked at Justice, the refusal to take positions that could not be defended by respectable standards did not harm the lawyer. As anyone who has ever worked in an organization knows, however, informal pressure can be an extraordinarily effective method of stifling disagreement and guiding decisions in the way top management desires. We know that supervision of the process of executive branch lawyering on the NSA memorandum was significantly usurped by the Office of the Vice President. David Addington, the Vice President's Counsel, and John Yoo, then a deputy in OLC, worked together to craft a series of arguments for unprecedented claims of executive power to pursue the campaign against terrorism. ${ }^{10}$ Jack Goldsmith reports that Addington blackballed from future advancement in the executive branch any lawyer who dared cross swords with him. ${ }^{11}$

The deficiencies of legal analysis of NSA surveillance were replicated in other initiatives after 9/11, including the treatment of persons captured and suspected of aiding and abetting terrorism. The Justice Department, through OLC, produced legal opinions stating, in effect, that anyone

the National Security Agency Described by the President 17 (2006), available at http://www.justice.gov/olc/2006/nsa-white-paper.pdf.

10. My account of Administration lawyering with regard to the warrantless surveillance program is based on Daniel Klaidman, Stuart Taylor, Jr. \& Evan Thomas, Palace Revolt, NEwsweEK, Feb. 6, 2006, at 34.

11. GoldSMITH, supra note 7, at 170-171. 
captured in the Afghanistan campaign had few, if any, rights under U.S. or international law and certainly no rights susceptible to vindication in U.S. courts. ${ }^{12}$ The function of these legal opinions - indeed, their obvious purpose - was to ratify a scheme of maximum license to do with the detainees whatever the military, the CIA, or any other U.S. authority might choose to do with them. The Administration's lawyering process cleared the path to horrors at the Abu Ghraib prison and Guantánamo - crimes whose stain upon our national honor is likely to remain, for decades at least, firmly embedded in the world's collective memory, deeply undermining our image and influence abroad.

It is understandable that the Administration would want some flexibility in dealing with a threat it rightly regarded as in some ways unprecedented and of very grave magnitude. And yet, to move the detainees so completely beyond the realm of normal legal process was itself a plainly risky strategy in terms of compromising international support, exposing U.S. military personnel to mistreatment, risking the honor of U.S. military culture, and weakening the fabric of international law generally in its protection of both combatants and civilians during wartime. The desire for flexibility was understandable, but not at the cost of all other values.

On a number of the most important points discussed in the OLC lawyers' memoranda, the courts subsequently held them to be wrong. Contrary to OLC, the Supreme Court held that foreign detainees at Guantánamo who challenged their classification as enemy combatants were entitled to judicial review of the legality of their detention. ${ }^{13}$ Contrary to OLC, the Court held that the Geneva Conventions protected the detainees, whether or not they strictly qualified as prisoners of war. ${ }^{14}$ Contrary to OLC and Justice Department briefs, the Court held that the military commissions as originally constituted were not sufficiently protective of the detainees' rights to permit their use for war crimes trials. ${ }^{15}$

On all of these questions, whether of morality, policy, or law, there were at least serious arguments to be entertained by both sides. The fact that the Administration reached incorrect conclusions is, in itself, only a limited indictment of its lawyering. Even good lawyers make mistakes, and the fact that executive branch lawyers would consistently make mistakes erring on the side of executive authority is not in itself damning. What is damning, however, is that on critical questions - questions going to the core of national honor and identity - executive branch lawyering was not just

12. The key memos are reprinted in Karen J. Greenberg \& Joshua L. Dratel, The Torture PAPERs: The RoAd to Abu GHraib 3-24, 38-222 (2005) [hereinafter Torture PAPERS].

13. Rasul v. Bush, 542 U.S. 466, 484 (2004).

14. Hamdan v. Rumsfeld, 548 U.S. 557, 627-631 (2006).

15. Id. at 634-635. 
wrong, misguided, or ethically insensitive. It was incompetent. It was so sloppy, so one-sided, and at times so laughably unpersuasive that it cannot be defended as ethical lawyering in any context. Tax advice this bad would be malpractice. Government lawyering this bad should be grounds for discharge.

With regard to federal statutes to implement the U.S. obligation to enforce the Convention Against Torture (CAT), an OLC memo states, flat out, that the President may simply ignore the law. Without any authority, the opinion announces ex cathedra: "Any effort by Congress to regulate the interrogation of battlefield combatants would violate the Constitution's sole vesting of the Commander-in-Chief authority in the President."16 That is a stunning proposition, and one that no worthy legal adviser would advance without due examination of counterarguments. A competent legal memorandum on this particular point would consider the implications of constitutional text pointing conspicuously in the other direction: the sole vesting in Congress of the power to make laws necessary and proper to carrying executive authorities into effect, and the vesting in the President of the obligation to take care that the laws be faithfully executed, which, at its core, is a bar against the Executive's suspension of statutes. This OLC memorandum represents the extremes of presidentialism, a tendency to express disregard, even disdain, for other opinions, and to argue by fiat in the belief that the rightness of a largely unprecedented position is selfevident, beyond dispute, and to be taken on faith.

In an effort to define physical torture, OLC lawyers relied on the idea that other statutes with similar phrasing may shed light on the textual meaning in question through analogy. They turned to statutes that refer to "severe pain" and ended up citing statutes that define emergency medical conditions that entitle their victims to federally funded health benefits. To count as "torture," physical pain would have to be of comparable severity to the pain that would entitle its sufferer to government-provided health insurance. This is an amazing performance. I think we can safely assume that, whatever policy considerations underlie the structuring of our Medicare statutes, they probably have nothing to do with the policies underlying the CAT. In defining "severe pain" for emergency health insurance purposes, Congress was presumably creating a very narrow entitlement to fill a hole in a much more comprehensive scheme of health insurance. This has nothing to do with levels of brutality appropriate to military detainees. Looking at health insurance statutes to determine the meaning of torture is a little like defining the rules in a "court" of law by

16. Memorandum of Jay S. Bybee, Assistant Attorney General, U.S. Department of Justice for Alberto Gonzales, Counsel to the President, Re: Standards of Conduct for Interrogation Under 18 U.S.C. $\$ \$ 2340-40 A$ (Aug. 26, 2002), reprinted in TORTURE PAPERS, supra note 12, at 172, 207. 
looking up the rules that apply to a basketball "court." It is more of a play on words than serious lawyering. ${ }^{17}$

\section{RESTORING LEGAL COMPETENCY}

The Office of Legal Counsel exists as an office outside the White House precisely to insure that the President's legal advice has some measure of independence to it. OLC includes both political appointees and "career employees," the latter often long-time members of the office whose institutional memory spans more than a single presidency. However predisposed it may be to uphold plausible assertions of executive power, OLC is traditionally mindful of its quasi-adjudicative role. It is supposed to be a conscientious adviser to the President and to the Attorney General, not their blind advocate. ${ }^{18}$ The location of OLC outside the White House, its reliance on career lawyers as well as political appointees, and the quasiadjudicative norms that traditionally shape OLC legal advice are intended to mitigate the gravitational pull of politics. Especially in contexts where the executive branch works in secrecy and largely free of either judicial review or close congressional oversight, the dedication to a balanced, dispassionate, multivocal approach to legal interpretation is indispensable to any meaningful adherence to the rule of law.

The process of securing legal analysis after September 11 was anything but balanced, dispassionate, and multivocal. Genuine influence was deliberately limited to a group of lawyers united by ideology, not only in terms of amenability to claims of executive power, but also in hostility to international law, a likely source of constraint on that power. Members of the group wanted to distinguish themselves by the risks they were willing to advocate in order to maximize the President's flexibility. Despite the number of immediate legal questions that would affect military personnel, military lawyers were largely excluded from the key legal deliberations following September 11. Then-White House Counsel Alberto Gonzales, with little national security experience, was exposed to the views of the Vice President's Counsel, David Addington, an extreme presidentialist, and Deputy White House Counsel Timothy Flanigan, an alumnus of OLC during its aggressively presidentialist days under President George H. W. Bush. Other key figures, like John Bellinger, the National Security Council's top lawyer, were not even told of their plans.

Addington brought John Yoo into the circle. As an academic, Yoo had written an article indicating that Congress's constitutional power to declare

17. For further evaluation of OLC's analogy between the torture statute and the health statute, see SHANE, supra note 3, at 101-103.

18. See generally Walter E. Dellinger, et al., Principles To Guide the Office of Legal Counsel, 81 IND. L. J. 1348 (2006). 
war had no bearing on the President's unilateral authority to deploy American military force wherever and whenever he likes. Yoo was ultimately lead author of the infamous torture memo, but his thinking was foreshadowed by an earlier memo he wrote shortly after September 11, which declared that Congress may not "place any limits on the President's determination as to any terrorist threat, the amount of military force to be used in response, or the method, timing, and nature of the response." ${ }^{\text {,19 }}$ Led by Timothy Flanigan, the inner circle of Administration lawyers researching the use of military commissions did not turn to State Department legal adviser William H. Taft IV for his input on U.S. treaty obligations towards military detainees. They did not trust him to toe the line on extreme presidentialism, even though he had served in the Reagan administration. ${ }^{20}$

Perhaps the most celebrated of the attorneys who sought to slow the Administration's embrace of unlimited discretion with regard to the treatment of detainees is Albert J. Mora, who served from 2001 to 2006 as General Counsel to the Navy. ${ }^{21}$ As succinctly stated by reporter Jane Mayer, his 2004 memo shows that "Mora tried to halt what he saw as a disastrous and unlawful policy of authorizing cruelty toward terror suspects. .. . Mora's criticisms of Administration policy were unequivocal, wideranging, and persistent." ${ }^{22}$ William Haynes, the Pentagon's General Counsel, who was a protégé of Addington's, told Mora in January 2003, that Defense Secretary Donald Rumsfeld was suspending harsh interrogation techniques and convening a working group to develop interrogation guidelines; he did not reveal that the working group would be following the August 2002 OLC "torture memo" authored by John Yoo.

The theory that the President is accountable to no one invites a style of decisionmaking in which any dissent from the expansion of executive power is regarded not merely as wrong, but disloyal. Dissenters do not just lose arguments; they are punished. The tension between presidentialism and the rule of law is not just a matter of principle. Presidentialism licenses a style of executive policy making that, in utterly foreseeable ways, makes certain types of violations of law more likely. Aggressive presidentialism does not produce superior decisions in terms of wisdom or attractiveness as public policy. Instead, the pattern we have seen with regard to previous

19. Memorandum from John Yoo, Deputy Assistant Attorney General, U.S. Department of Justice, Office of Legal Counsel, to Timothy Flanigan, Deputy Counsel of the President, The President's Constitutional Authority To Conduct Military Operations Against Terrorist Organizations and the Nations that Harbor or Support Them (Sept. 25, 2001), reprinted in TORTURE PAPERS, supra note 12, at 3, 24.

20. Tim Golden, After Terror: A Secret Rewriting of Military Law, N.Y. TIMES, Oct. 24,2004 , at 13 .

21. This account is derived from Jane Mayer, The Memo, NEw Yorker, Feb. 27, 2006, at 32.

22. Id. 
administrations - constricted debate among the like-minded - produces decisions at odds with even the executive branch's professed vision of the national interest. Surely, no policy maker in the Bush administration would have argued for antagonizing the world's Muslim population as a way of advancing America's policies and global position. Yet, as described jointly by attorney Joseph Margulies, who successfully established the right of Guantánamo prisoners to habeas corpus, and Lawrence Wilkinson, who served from 2002 to 2005 as Secretary of State Colin Powell's Chief of Staff: "Guantánamo has become a word that inspires rage for millions of Muslims," ${ }^{23}$ essentially because of Bush administration policies that its lawyers effectively sanctioned.

Presidentialism in action distorts the processes of legal analysis that are supposed to serve as a protection against the abuse of power. No sane President claims to be above the law, and every administration will take pains to defend controversial actions as legal. The defense by the Bush administration after $9 / 11$ of extraordinary rendition is typical: "In addition to the terrorists held at Guantánamo, a small number of suspected terrorist leaders and operatives captured during the war have been held and questioned outside the United States, in a separate program operated by the Central Intelligence Agency. . . . This program has been subject to multiple legal reviews by the Department of Justice and CIA lawyers; they've determined it complied with our laws." ${ }^{24}$

What the Bush record confirms, however, is that "legal reviews" by self-interested lawyers within an administration devoted to supporting presidential goals are often insufficient by themselves to satisfy the rule of law. The "suspected terrorist leaders and operations" were clearly suspects and many of them, apparently absolved, were released by the Administration after abusive interrogations. Mistakes are made because legal analysis within the confines of one branch of government, especially when done in secret to carry out national security policy, lacks the level of accountability that the rule of law demands.

Checks and balances, in operation, depend on an assemblage of norms, cooperative arrangements, and informal coordination activities, both within and between branches. Jack Goldsmith wrote about the critical role of institutional norms in preserving the rule of law within the executive branch. In order to prevent itself from simply interpreting the law opportunistically to serve the political ends of the executive branch, OLC "has developed powerful cultural norms about the importance of providing

23. Joseph Margulies \& Lawrence Wilkerson, Op-Ed, Guantanamo Prison Observes Sad Anniversary, MiAmi HeRALD, Jan. 28, 2007.

24. Press Release, President Discusses Creation of Military Commissions To Try Suspected Terrorists (Sept. 6, 2006), available at http://georgewbush-whitehouse.archives. gov/news/releases/2006/09/20060906-3.html. 
the President with detached, apolitical legal advice, as if OLC were an independent court inside the executive branch." ${ }^{25}$ His statement echoes the observations of a group of former OLC attorneys, led by former Assistant Attorney General Walter Dellinger, who were deeply upset by the national security opinions written by attorneys within the Bush administration after $9 / 11$. $^{26}$ The robustness of these rule of law norms, however, is powerfully buttressed by the interaction of the executive branch with Congress and the judiciary. The internal norms rightly underscored by Dellinger and Goldsmith are unlikely to be self-sustaining without external reinforcement.

If we read the academic work of the presidentialists, their position becomes clear. They feel justified in elevating Article II over Article I because they regard the executive branch as a better institution than Congress. They think it better at making decisions because it is more centralized and hierarchical. ${ }^{27}$ They may think it is better at handling sensitive information because of the same structural features. And, most notably, they think it more reliable in pursuing the national interest because the President, unlike his legislative colleagues, is accountable to a national constituency, thus supposedly fostering an accountability to the general interest that is less parochial, less factional, than the perspectives of individual members of Congress. ${ }^{28}$

These normative claims are important to evaluate, especially because the last is a red herring - the proper comparison is not between the President and a member of Congress, but between the President and Congress as a body - and the others are easily overstated. The Framers of our Constitution did not share this sense of executive branch superiority for making policy decisions. On the contrary, they designed an elaborate and pluralistic legislative process out of the conviction that Congress's structural characteristics - its size and bicameral design - were superior for resolving issues of public policy because they would insure due discussion and thorough deliberation. To the extent presidentialism embraces informal norms of governance or legal interpretations that disrespect the role and perspective of Congress, presidentialism is at odds with constitutional originalism.

My strategy, however, in painting the dangers of presidentialism is to rely ultimately not on theory, but on experience. The performance of the Bush administration gave Americans a kind of natural experiment in how the presidentialists' attitude plays out in practice, and it is the record of that

25. GoLDSMITH, supra note 7 , at 33 .

26. Dellinger, supra note 18.

27. Lawrence Lessig \& Cass R. Sunstein, The President and the Administration, 94 Colum. L. ReV. 1, 106 (1994).

28. See generally Steven G. Calabresi, Some Normative Arguments for the Unitary Executive, 48 ARK. L. REV. 24 (1995). 
administration that indicts the presidentialist vision of the rule of law most effectively.

The fact that prior Democratic administrations, including that of Lyndon B. Johnson, occasionally displayed the same damaging dependence on unchecked executive power, secrecy, and deception, means that the defects of presidentialism are not partisan, but structural.

Healthy checks and balances in a separation of powers system like ours depend on informal practices of cooperation and mutual respect among the branches of our federal government. For at least the last quarter century, many of these key informal practices, which have long helped to sustain effective governance in the United States, have withered. Their decline has accelerated the ascent of executive power at least since the second Reagan administration. Through a variety of rules and institutional practices, many voices within our national democratic conversation have been artificially suppressed. What we need is more democracy to level the playing fields of electoral competition and democratic deliberation. No feature of government is more essential to democratic legitimacy than the ongoing pervasiveness within government of free and open dialogue. Checks and balances were intended to protect the republic by restraining the capacity of any one branch to rule tyrannically by "checking" unwise initiatives.

Executive unilateralism legitimates secrecy, and secrecy promotes effective decisionmaking in the public interest only in exceptional circumstances. An administration's conspicuous availability to have its performance subjected to public scrutiny will improve both the quality of that performance and public confidence in the executive branch. President Franklin D. Roosevelt in September 1940 decided to give Great Britain fifty "over-aged" destroyers in exchange for military bases in the Western Hemisphere. Roosevelt concluded that it was best to release to the public the legal reasoning of Attorney General Robert Jackson, rather than proceed in secrecy. Jackson's opinion did not persuade everyone, but Roosevelt strengthened his hand by acting publicly. As Jack Goldsmith has pointed out, having Jackson's opinion published in the pages of The New York Times was an important method of undercutting the objections of those who objected on legal grounds. ${ }^{29}$ Roosevelt took some risks in going public. The risks of acting in secret, however, are much greater. To Goldsmith, the kind of strategy employed by the Bush administration after 9/11 "is guaranteed not to work, and is certain to destroy trust altogether.,"30

In his review of legal advice offered by recent administrations, former law dean and fellow OLC alumnus Harold Bruff inquires into the lessons of history: "Will the public beatings Bush administration officials have

29. GolDSMITH, supra note 7, at 199.

30. Id. at 212 . 
received deter their successors from repeating their excesses? Recent experience suggests not. It was about a decade from Watergate to IranContra, and another fifteen years to the war on terror. Attempts to aggrandize the executive branch have produced some punishments in each case, but the sting does not seem to last very long." ${ }^{31}$ What plausible remedies exist to sanction government attorneys who act unprofessionally? The counseling function is covered by the American Bar Association's Model Rules of Professional Conduct. Rule 2.1 provides that, in representing a client, a lawyer is expected to "exercise independent professional judgment and render candid advice.", Bruff notes that a leading legal ethics treatise warns that a lawyer may not simply reinforce the preferences of a client:

A client may consult a lawyer to have her own preconceptions confirmed rather than to seek genuine advice. A lawyer may be tempted to play sycophant to such a client, to ensure continued employment. Rule 2.1 prohibits such an approach, however, first by requiring that a lawyer's advice be candid; and second, by requiring the lawyer to exercise judgment that is both independent and professional. ${ }^{33}$

Lawyers within the executive branch who fail to discharge the obligations of Rule 2.1 are subject to sanctions, ranging from rebuke to disbarment. We are all familiar with the lax enforcement of this rule against government attorneys. Many attorneys and public officials paid a price for Watergate, including prison sentences, but there has been little in the way of penalties in subsequent years. There are strong reasons for the public to insist on higher standards, both to guide government attorneys in the future, and to assure a commitment to democracy, constitutional government, and the rule of law. Unless these standards are strengthened, clarified and enforced, there is every reason to worry about the capacity of the executive branch to provide reliable legal and constitutional analysis in times of emergency.

31. BRUFF, supra note 1 , at 289.

32. Id. at 294-295, citing Model Rules of Prof'L ConduCt R. 2.1 (2003).

33. Id. at 295 (quoting 1 Geoffrey C. HaZArd, JR. \& William H. Hodes, The Law OF LAWYERING (3d ed. 2001), at §23.2). 